\title{
SOIL EROSION BY TILLAGE IN RAINFED N-W. EGYPTION COAST

\author{
Salem $^{2}$, A.M.; M.N. Awady ${ }^{1}$; M.M. Wassif ${ }^{2}$ and E.A.S. El Sahhar ${ }^{1}$ \\ 1- Agric. Eng. Dept. Fac. of Agric., Ain Shams Univ., Cairo, Egypt \\ 2- Soil Conservation Dept., Desert Research Center, Cairo, Egypt
}

Keywords: Soil erosion, Tillage erosion, Chisel tillage, Soil translocation

\begin{abstract}
Tillage erosion is one of the main causes of land degradation. The objective of the present study is to evaluate the effect of tillage systems (up and downslope and contour tillage), soil conditions (consolidated and loosened soils), tillage depth, speed and slope on tillage erosion rate. Field experiments of variable slopes (3 - 16\%) were established on sandy soil of Wadi El Ramala, west Mersa Matruh City. Soil translocation as affected by tillage systems and soil conditions were examined. In addition, soil losses by tillage erosion and water erosion were measured and evaluated.

The experimental results showed that the average displacement distance is a function of gradient slopes, soil condition, tillage system, depth and speed. The validation of the soil translocation model developed by (Van Muysen et al 2000), under different gradient slopes, tillage depth, speed and soil condition were evaluated. This validation showed that variations in tracer displacement distance can be successfully predicted. Consequently, such model can be used under sandy soil. Finally, experiment results showed that tillage operations with a chisel plow under present agricultural practices are responsible for the major field redistribution of soil. Furthermore, it is clear that tillage of a loosened soil is far more erosive than tillage of a consolidated soil, where the tillage transport coefficient $(\mathrm{K})$ was $105 \mathrm{~kg} \cdot \mathrm{m}^{-1}$ per tillage operation for consolidated soil and $179 \mathrm{~kg} \cdot \mathrm{m}^{-1}$ for loosened soil under contour tillage. However, 256 $\mathrm{kg} \cdot \mathrm{m}^{-1}$ per tillage prevailed for consolidated soil and $454 \mathrm{~kg} \cdot \mathrm{m}^{-1}$ for loosened soil under up and downslope tillage treatments.
\end{abstract}

\section{INTRODUCTION}

Tillage is one of the fundamental practices of soil management. It is the procedure by which man disturbs, overturns and rearranges the soil to create favorable soil physical conditions for seedbed preparation. The objectives of tilling include changing soil bulk density, and modifying pore-size distribution, water holding capacity, infiltration rate, penetration resistance and soil aeration. Each soil type or cropping system responds differently to tillage. Tillage is important in soil erodibility, Although the direct movement of soil by tillage is usually ignored (Govers et al 1999).

Under rainfed agriculture, tillage activities are believed to move relatively more soil downward during downslope tillage than upward during upslope tillage, which leads to an overall net downslope translocation. As such, tillage redistributes soil in hilly regions, causing spatial variability in soil quality (Dercon et al 2003). This redistribution is affected by both soil characteristics and tillage operation properties. The slope gradient, due to the gravity driven nature of the process, is especially known to have a major influence. Furthermore, implement characteristics and speed direction, and depth of tillage have an effect on the rate of soil translocation. The terms tillage erosion and tillage translocation are often used intermittently (Lindstrom et al 1990).

Various definitions for tillage erosion are given in literature. Tillage erosion is the redistribution of soil within a landscape caused directly by tillage (Govers et al 1999). (Van Muysen et al 2000) defined tillage translocation as the movement of soil due to tillage in general and tillage erosion is considered when tillage translocation in direction is larger than tillage translocation in the opposite direction and thus a net tillage translocation occurs. (Lindstrom et al 2001) define it as "the net move- 
ment of soil downslope through the action of mechanical implements". Meanwhile, (Lobb et al 1999) use the definition " net downslope translocation of soil material by tillage". However (Lobb et al 1995) provide a broad definition: "the loss and accumulation of soil resulting from the variable translocation of soil by tillage". Consequently, both components of the erosion process, i.e., the erosion of soil material at specific landscape positions (tillage erosion) as well as the subsequent deposition of this eroded material at other positions (tillage deposition), are explicitly denoted.

Marques da Silva et al (2004) showed that soil translocation by tillage is strongly affected by slope gradient. This relationship between soil translocation and slope gradient has been observed under various agri-environmental conditions. The variation of soil translocation with slope results in tillage erosion.

It has long been recognized that tillage operations cause the translocation of substantial quantities of soil (Lindstrom et al 1990). Experimental studies on tillage translocation were mostly related to the design and performance of soil working implements. In this respect, Kimaro et al (2005) studied the mixing and sorting action of tines in the field, while (Sharifat et al 1994). investigated the effect of implementing type and tillage speed on soil movement.

The most widespread model to describe tillage translocation is the diffusion model proposed by Govers et al (1994). They calculated the transport rate $Q_{s}$, direction $\left(\mathrm{kg} . \mathrm{m}^{-1}\right)$ i.e. the mass of soil moved in a direction per meter width of tillage. Qs Needs to be calculated for each tillage operation with its own set of specific conditions (slope, net mean downslope displacement, bulk density, average tillage depth). These operating conditions are usually represented by a tillage transport coefficient (K) (Van Muysen et al 2006). This tillage transport coefficient is a measure of the tillage erosivity for a given tillage operation and can be used to calculate tillage erosion rates-high values corresponding to high tillage erosion rates. Different values of the tillage transport coefficient $(\mathrm{K})$ had been calculated by several investigators and ranged between 111 and $657\left(\mathrm{~kg} \mathrm{~m}^{-1}\right.$ per tillage operation) for chisel tillage.

Govers et al (1994) found that the highest translocation rates occurred on the steepest slopes, decreasing gradually when moving to less steep slopes. They added that the largest part of soil translocation was moreover caused by primary operations such as chisel- and moldboard tillages.
However, according to Lindstrom et al (2001), an important amount of soil is moved by secondary operations (harrowing and seeding) as well.

Using sweeps, the effect of tillage speed on tillage translocation in the direction of the tillage has been investigated by Sharifat and Kushwaha (1997). They noted that higher tillage speeds resulted in larger lateral displacement distances. Lobb et al (1999) investigated the effect of tillage depth and tractor speed on tillage translocation. Although their results suggested that these effects were significant, the identified relationships were neither consistently nor strong. They attributed this to the confounding role of other factors, such as the tractor-implement match and the responsiveness of the tillage operator.

Most methods estimated the tillage translocation rate based on experimentally determined soil movement due to tillage. One of them is the tracer method, which is accurate and most widespread, even though it is very timely-demanding (Lobb et al 2001). The technique basically consists of incorporating a tracer in the soil and comparing its distribution before and after tillage. The use of individually labeled objects as point tracers has the advantage of characterizing the complexity of soil redistribution, since the movement of every tracer can be measured.

Information on the effects of tillage system, soil condition, tillage speed and tillage depth on soil erosion by tillage is a prerequisite for allowing erosion rates to be predicted and to reduce tillage erosion. Therefore, the main objective of this investigation was to study the effects of tillage systems, initial soil condition, tillage speed, tillage depth, and slope gradient at the moment of tillage, on the soil translocation and tillage erosion rate.

\section{MATERIALS AND METHODS}

\section{Study area}

Wadi EL-Ramla area was selected to carry out the experiment. It is located south-west Mersa Matruh City. The experimental site lies between Latitudes $31^{\circ} 15^{\prime} 35^{\prime \prime}$ and $31^{\circ} 18^{\prime} 15^{\prime \prime} \mathrm{N}$ and between Longitudes $27^{\circ} 9^{\prime} 43^{\prime \prime}$ and $27^{\circ} 10^{\prime} 57^{\prime \prime} \mathrm{E}$. The maximum slope of the experimental site is about 0.16 $\mathrm{m} . \mathrm{m}^{-1}$ and the slope length along the profile is approx. $50 \mathrm{~m}$ in north-south direction. This slope has a convex profile with a sharp basal concavity near the thalweg. At the time of the experiment, the slope was left under natural vegetation for five years. The climate is characterized by long hot dry 
summer and short cool, rainy winter typical of subarid region, defined as "Arid Mediterranean". In general, monthly temperature varied between 14.4 and $26.8{ }^{\circ} \mathrm{C}$, wind speed averaged at $18.9 \mathrm{~km} / \mathrm{h}$., and the average annual rainfall ranged from 100 to $190 \mathrm{~mm}$ (Khalifa and Beshay, 2015).
A detailed contour map of the study area was constructed using an automatic theodolite (Fig. 1). Soil of Wadi EL-Ramla is mainly sandy loam in texture. The plow layer was compacted with mean soil bulk density $1.45 \mathrm{~g} / \mathrm{cm}^{3}$. Surface and subsurface soil samples $(0-20 \mathrm{~cm}, 20-40 \mathrm{~cm})$ were collected to describe the soil properties. Such soil properties are given in Table (1).

Table 1. Summary of site description and experimental setup

\begin{tabular}{|c|c|c|c|c|c|c|c|}
\hline $\begin{array}{l}\text { Tillage } \\
\text { system }\end{array}$ & $\begin{array}{c}\text { Soil } \\
\text { condition }\end{array}$ & Profile & Strips & & $\begin{array}{c}\text { Tillage } \\
\text { depth }(m)\end{array}$ & $\begin{array}{l}\text { Tillage } \\
\text { speed } \\
\left(\mathrm{m} . \mathrm{s}^{-1}\right)\end{array}$ & $\begin{array}{c}\text { Bulk } \\
\text { density } \\
\left(\mathrm{kg} \cdot \mathrm{m}^{-3}\right)\end{array}$ \\
\hline \multirow{2}{*}{$\begin{array}{l}\text { Up and } \\
\text { downslope } \\
\text { tillage }\end{array}$} & $\begin{array}{l}\text { Consoli- } \\
\text { dated soil }\end{array}$ & $\left(A_{1}-A_{6}\right)$ & 60 & $\begin{array}{l}\text { Average } \\
\text { per strip } \\
\text { Range } \\
\text { (min-max) }\end{array}$ & $\begin{array}{c}0.15 \\
0.07-0.20\end{array}$ & $\begin{array}{c}1.59 \\
0.95-2.3 \\
\end{array}$ & $\begin{array}{c}1595 \\
1500-1670\end{array}$ \\
\hline & $\begin{array}{l}\text { Loosened } \\
\text { soil }\end{array}$ & $\left(B_{1}-B_{2}\right)$ & 20 & $\begin{array}{l}\text { Average } \\
\text { per strip } \\
\text { Range } \\
\text { (min-max) }\end{array}$ & $\begin{array}{c}0.20 \\
0.14-0.24\end{array}$ & $\begin{array}{c}1.98 \\
1.63-2.5\end{array}$ & $\begin{array}{c}1344 \\
1215-1395\end{array}$ \\
\hline \multirow{2}{*}{$\begin{array}{c}\text { Contour } \\
\text { tillage }\end{array}$} & $\begin{array}{l}\text { Consoli- } \\
\text { dated soil }\end{array}$ & $\left(A_{7}-A_{8}\right)$ & 10 & $\begin{array}{c}\text { Average } \\
\text { per strip } \\
\text { Range } \\
\text { (min-max) }\end{array}$ & $\begin{array}{c}0.15 \\
0.13-0.17\end{array}$ & $\begin{array}{c}1.75 \\
1.63-1.85\end{array}$ & $\begin{array}{c}1555 \\
1510-1595 \\
\end{array}$ \\
\hline & $\begin{array}{l}\text { Loosened } \\
\text { soil }\end{array}$ & $\left(\mathrm{B}_{3}-\mathrm{B}_{4}\right)$ & 10 & $\begin{array}{l}\text { Average } \\
\text { per strip } \\
\text { Range } \\
\text { (min-max) }\end{array}$ & $\begin{array}{c}0.20 \\
0.18-0.23\end{array}$ & $\begin{array}{c}1.92 \\
1.75-2.05\end{array}$ & $\begin{array}{c}1320 \\
1275-1370\end{array}$ \\
\hline
\end{tabular}

\section{Experimental setup}

Two sets on the hillslope were selected to carry out the experiments. The treatments included; two tillage systems (up-downslope tillage and contour tillage) in addition to two soil conditions (consolidated soil and loosened soil).

\section{The treatments were as follows}

1- Chisel tillage of a consolidated soil under natural vegetation (first pass), contour tillage $\left(\mathbf{T}_{1}\right)$.

2- Chisel tillage of a loosened soil (second pass), contour tillage $\left(\mathbf{T}_{2}\right)$.

3- Chisel tillage of a consolidated soil under natural vegetation (first pass), up and downslope tillage $\left(\mathbf{T}_{3}\right)$.

4- Chisel tillage of a loosened soil (second pass), up and downslope tillage $\left(\mathbf{T}_{\mathbf{4}}\right)$.

Tillage speed was estimated during the experiment by measuring the time needed for the tractor to travel $10 \mathrm{~m}$ across the strip. Tillage depth was estimated as the average difference in elevation between the bottom of the plow layer, as recorded after excavation of the tracers, and the elevation of the soil surface in the same location, as derived from the detailed digital elevation model.

The first set $(A)$ refers to a situation where the consolidated soil is taken back into cultivation after a long fallow period. In this treatment, eight slope profiles $\left(A_{1}-A_{8}\right)$ were selected, the first six slope profiles for up and downslope tillage and the last two slope profiles for contour tillage Fig. (2). The second set (B) was tilled once in the up and downslope directions with a duck-foot chisel plow two days before the actual experiment in order to obtain a freshly loosened soil. For this treatment, four profiles $\left(B_{1}-B_{4}\right)$ were delineated, the first two slope profiles were for up and downslope tillages and the last two slope profiles for contour tillage, Fig. (3). All strips were perpendicular to the tillage direction. For each strip, slope gradient, tillage depth and tractor speed were recorded. 

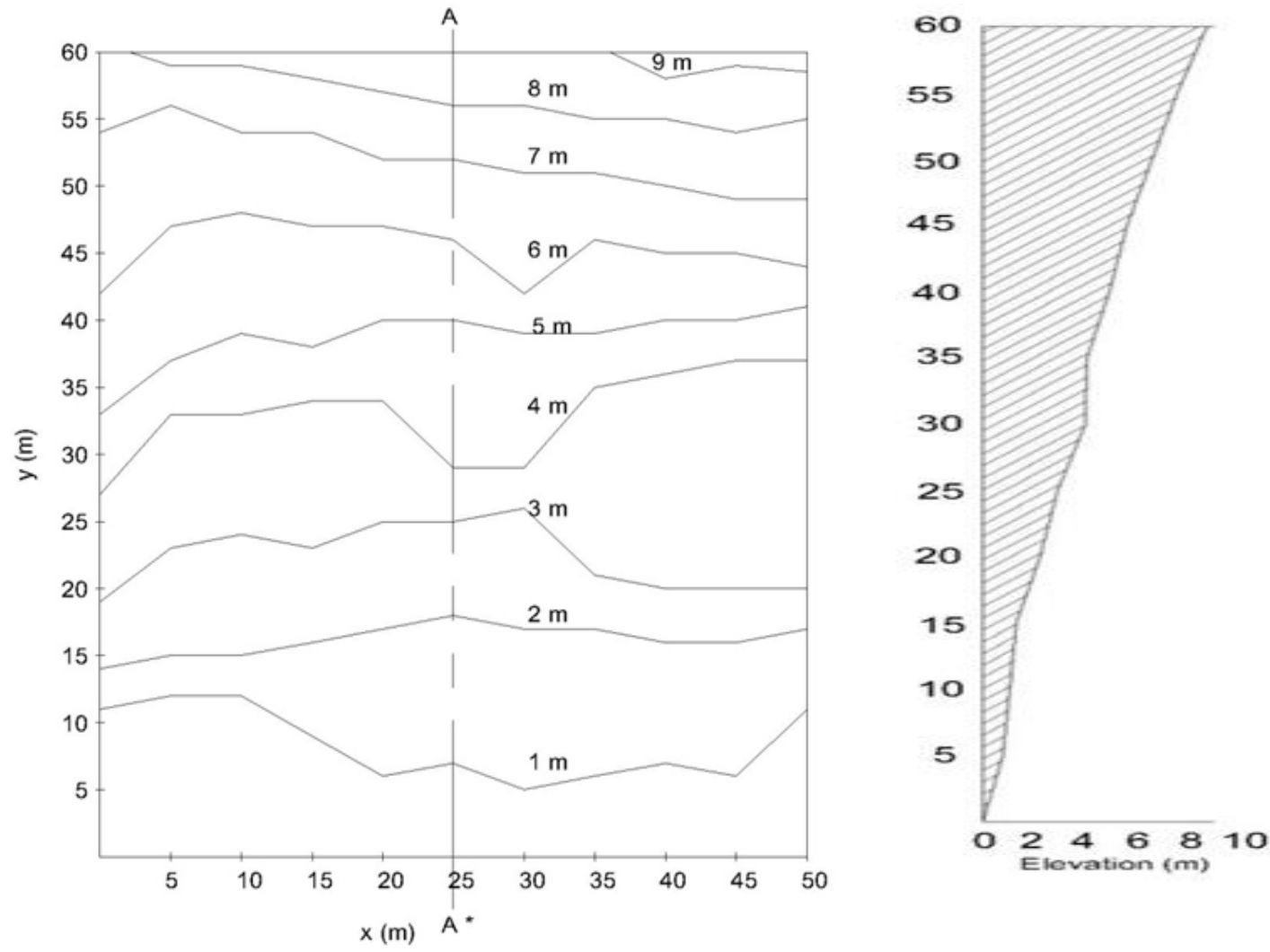

Fig. 1. A detailed contour map of the study area.

On each profile, 5 to 10 strip plots perpendicular to the tillage direction and on varying slope gradients, were established. Positioning of the strip plots on the different profiles ensured that half of the strip plots were tilled in the upslope direction and the other half in the downslope direction. For the consolidated soil treatment, 70 strip plots (ca. 1 $\mathrm{m}$ wide) on varying slope gradients were established (with an average of 40 tracers per strip) and 30 strip plots for the loosened treatment (with an average of 45 tracers per strip).

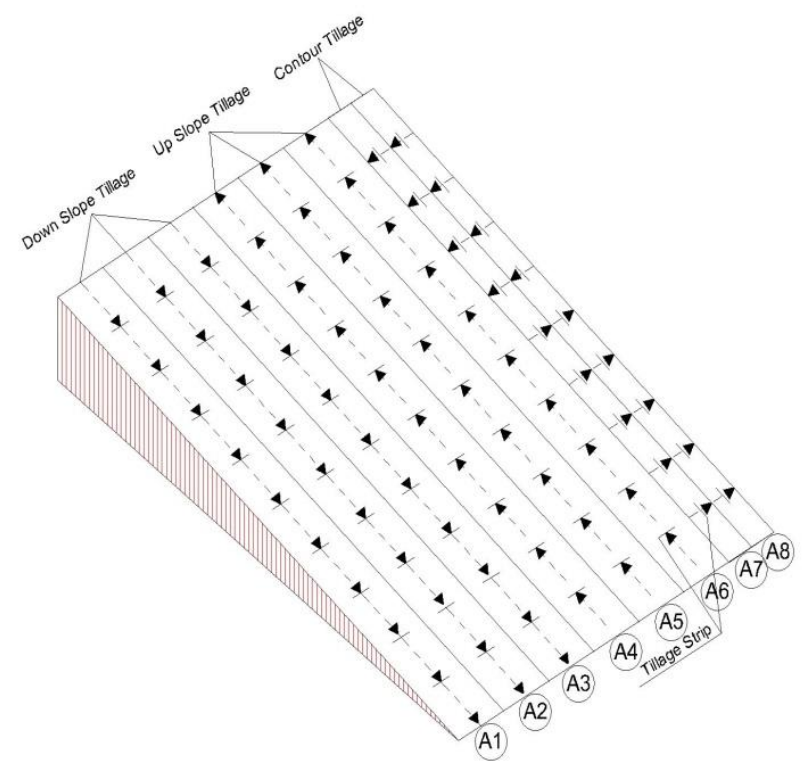

Fig. 2. Consolidated soil treatment 


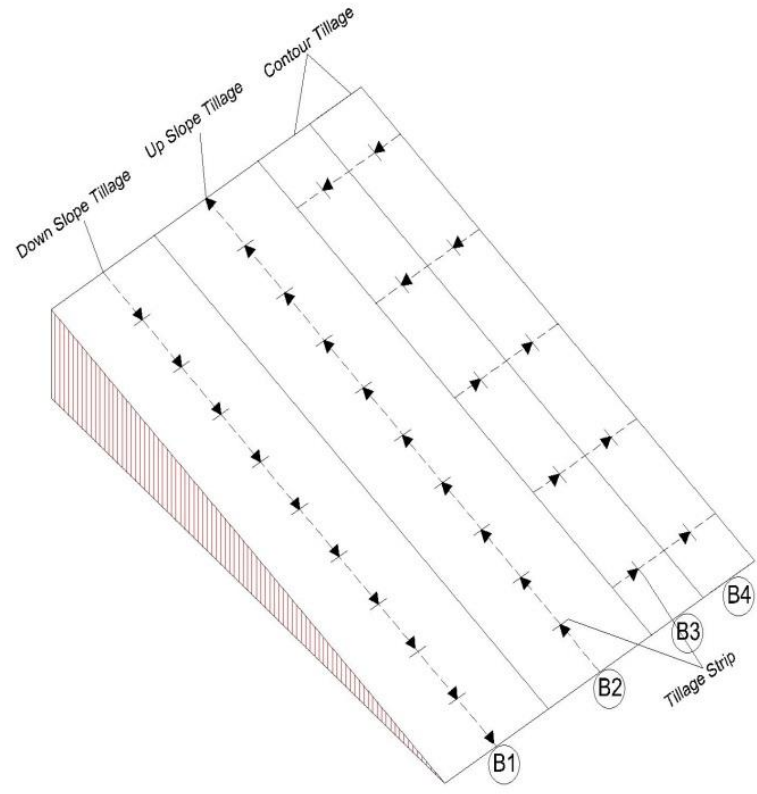

Fig. 3. Loosened soil treatment.

\section{Soil movement measurements}

To study soil movement, painted aluminum cubes with a side length of $15 \mathrm{~mm}$ were used as tracers because their density $\left(2635 \mathrm{~kg} / \mathrm{m}^{-3}\right.$ is similar to that of quartz $\left(2650 \mathrm{~kg} / \mathrm{m}^{-3}\right)$ (Poesen et al 1997). To insert the tracers for a consolidated treatment, the hole drilling technique as described by (Govers et al 1994) was used. On each strip, a series of 10 holes, with a diameter of approximately $2 \mathrm{~cm}$ were drilled at intervals of approximately 10 $\mathrm{cm}$. In principle, the holes were drilled $20 \mathrm{~cm}$ deep, but this was sometimes not possible due to the shallow soil depth, particularly upslope. A tracer was then inserted in the hole and its location was precisely recorded using an automatic theodolite. Next, the hole was filled with a known quantity of fine sand over a depth of approximately $5 \mathrm{~cm}$. Another tracer was then inserted and its position was recorded. This procedure was repeated until the hole was completely filled. The number of tracers that could be placed in each hole varied between four and five due to the variation in depth of the hole.

The loose condition of the soil of a freshly tilled, (second pass) prohibited drilling of holes. Therefore, a technique similar to the one used by (Poesen et al 1997) was used. On each strip, a narrow trench was dug approximately $25 \mathrm{~cm}$ wide, $1.2 \mathrm{~m}$ long and $25 \mathrm{~cm}$ deep. On the bottom of the trench, a series of tracers were deposited at intervals of approximately $10 \mathrm{~cm}$ and their individual position was recorded. The tracers were then covered with approximately $5 \mathrm{~cm}$ of soil. A new set of tracers was placed on top and their position was recorded as described above. This procedure was repeated until the trench was filled. Both procedures resulted in a good vertical distribution of the tracers throughout the plow layer Fig. (4). Both treatments were tilled using a Russian tractor pulling a duck-foot chisel (width about $=1.5 \mathrm{~m}, 3$ tines in front, followed by a row of 4 tines, width of the duck-foot about $=0.22 \mathrm{~m}$.

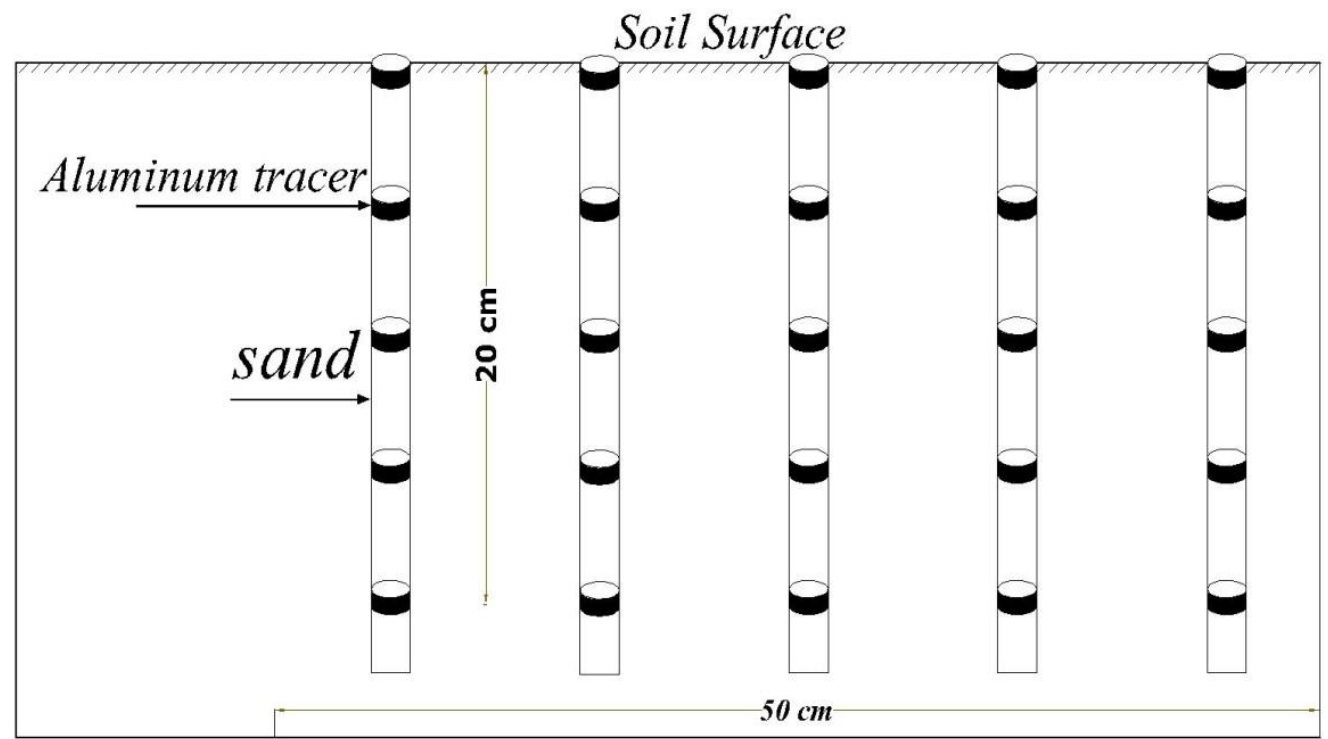

Fig. 4. Vertical cross-section of a tracer strip 
After one tillage, the tracers were dug out and their positions were recorded again with an automatic theodolite. At each site, the recovery rate of the tracers was in excess of $88 \%$. Individual horizontal displacement distances of the tracers were calculated. For contour tillage, the displacement distances were measured in the direction of the slope while for up- and downslope tillages, the displacement distances were measured in the direction of tillage, and these data were used in further analyses.

\section{Tillage erosion intensity}

The most common way to analyze tillage erosion experimental data, is by plotting the relationship between the mean displacement distance of the tracer in the tillage direction and the slope gradient in the direction of tillage, whereby the slope gradient is taken negative for downslope (when tracers moved downslope) and positive for upslope (Lindstrom et al 1990). If the relationship between the displacement distance and the slope gradient is linear, and tillage depth is constant, $(\mathrm{K})$ can be estimated as:

$K=-D \rho B$

\section{Where:}

$\mathrm{K}=$ the tillage transport coefficient $\left(\mathrm{kg} \mathrm{m}^{-1}\right.$ per tillage operation),

$\mathrm{D}=$ tillage depth $(\mathrm{m})$,

$\rho=$ bulk density of the soil $\left(\mathrm{kg} \cdot \mathrm{m}^{-3}\right)$, and

$B=$ the slope of the linear regression equation of the relationship between average tracer displacement " $\Delta \mathrm{x}$ " and slope gradient $(\mathrm{m})$.

The unit transport rate $Q\left(\mathrm{~kg} \cdot \mathrm{m}^{-1}\right)$ causing tillage erosion is then calculated as:

$$
Q=K * S
$$

Where:

$$
\mathrm{S}=\text { slope gradient (\%). }
$$

The relationship between displacement distance and slope gradient is not always linear: it may be different for (very) steep slopes (Poesen et al 1997).

However, the following more-general analysis is tried to yield relations between effective variables, as suggested by (Awady. 2017).
$\frac{\Delta x}{D}=f\left(S, \frac{U}{\rho * g * D}\right)$

$\frac{Q}{\rho * D^{2}}=f_{2}(S)$

Where:

$$
\begin{aligned}
& g=\text { gravity of the earth }\left(\mathrm{m} / \mathrm{s}^{2}\right) \\
& U=\text { unit draft }\left(\mathrm{N} / \mathrm{m}^{2}\right) \text { (Awady, 2006) }
\end{aligned}
$$

\section{Tillage erosion rates}

Tillage erosion rates associated with each $\mathrm{K}$ value are erosion rates (Van Muysen et al 2000). For a given topography, they can easily be calculated by calculating the difference between the amount of soil, leaving a specific slope element of unit width and the amount of soil entering the element, expressed as:

$$
E_{X}=\frac{Q_{s, o u t}-Q_{s, \text { in }}}{\Delta x}
$$

Where:

$E_{X}=$ the tillage erosion rate at position " $x$ " along a hillslope profile $\left(\mathrm{kg} \cdot \mathrm{ha}^{-1}\right)$.

$Q_{s, \text { out }}$ and $Q_{s}$, in = the net unit soil transport rate in the tillage direction along a hillslope profile that is respectively, leaving or entering the considered slope element (kg.m ${ }^{-1}$ per tillage operation).

$\Delta \mathrm{x}=$ the horizontal distance between each consecutive specific slope element $(\mathrm{m})$

\section{Mean displacement distance of the tracers in the direction of tillage predicted}

In order to validate the empirical model by (Van Muysen et al 2000), the mean displacement distance of the tracers in the direction of tillage under the prevailing conditions in the North West Coastal zone in Egypt was calculated according to the empirical model by (Van Muysen et al 2000). The obtained values ( $\left.\Delta \mathrm{x}_{\text {predd }}\right)$ were compared with the measured data obtained in the present experiments.

$$
\begin{aligned}
& \Delta x_{\text {predd }}=(0.266-0.928 S) *\left(\frac{D}{0.1}\right)^{-0.377} *\left(\frac{V}{1}\right)^{0.906} \text { * } \\
& (C)^{-0.729}
\end{aligned}
$$

Where:

$$
\begin{aligned}
& \Delta \mathrm{x}_{\text {predd }}=\text { predicted displacement distance }(\mathrm{m}), \\
& \mathbf{S}=\text { slope gradient }\left(\mathrm{m} \cdot \mathrm{m}^{-1}\right), \\
& \mathbf{D}=\text { tillage depth }(\mathrm{m}),
\end{aligned}
$$


$\mathbf{V}=$ tillage speed $\left(\mathrm{m} \cdot \mathrm{s}^{-1}\right)$, and

$\mathbf{C}=$ the soil condition factor was by convention taken to be 2 for the consolidated treatment and $\mathrm{C}$ $=1$ for the loosened treatment.

The use of equation (6) allows one to predict variations in displacement distances for slope gradients up to $0.25 \mathrm{~m} \mathrm{~m}^{-1}$.

\section{Measuring soil losses by water erosion}

Five bounded plots having edges of soil with approximately $20 \mathrm{~cm}$ height were used to determine soil loss, associated with runoff. Each plot was $10 \mathrm{~m}$ long and $2 \mathrm{~m}$ wide. At the down slope end, metal gutters were placed, $0.5 \mathrm{~m}$ long and 0.2 $\mathrm{m}$ wide, closed at the sides and covered with movable lid. An outlet pipe extended from the base of the gutter to the collection containers present below the soil surface.
The amount of soil loss and runoff water for every rainstorm was determined by maintaining the containers undisturbed for a sufficient time so that the solid constituents in the runoff water will precipitate. The precipitated solids were collected and measured gravimetrically after drying at the $105^{\circ} \mathrm{C}$ overnight.

\section{RESULTS AND DISCUSSION}

The field experiments were conducted in two successive winter seasons 2014-2015 and 20152016, at Wadi El-Ramla area, Mersa Matruh Governorate. Some physical and chemical properties of the soil experimental site are given in Table (2). It is clear that the soil is sandy loam in texture, CaCO3 content varies between 9.73 to $11.22 \%$, and the average bulk density is approximately 1.45 $\mathrm{g} . \mathrm{cm}^{-3}$. Table (2) shows that the soil is non-salt affected. The values of soil organic matter, total nitrogen, available phosphorus, and available potassium are very low.

Table 2. Some soil physical and chemical properties of the experimental site at Wadi El Ramla area

\begin{tabular}{|c|c|c|c|c|c|c|c|c|c|}
\hline \multicolumn{10}{|c|}{ a) Physical properties: } \\
\hline \multirow{2}{*}{$\begin{array}{l}\text { Soil depth } \\
\text { (cm) }\end{array}$} & \multirow{2}{*}{$\begin{array}{c}\text { Bulk } \\
\text { density } \\
\left(\mathrm{g} / \mathrm{cm}^{3}\right)\end{array}$} & \multicolumn{6}{|c|}{ Particle size distribution (\%) } & \multirow{2}{*}{$\begin{array}{c}\mathrm{CaCO}_{3} \\
(\%)\end{array}$} & \multirow{2}{*}{$\begin{array}{l}\text { Texture } \\
\text { class }\end{array}$} \\
\hline & & \multicolumn{2}{|c|}{$\begin{array}{c}\text { Coarse } \\
\text { sand }\end{array}$} & & Silt & Clay & & \\
\hline $0-20$ & 1.42 & \multicolumn{2}{|c|}{3.69} & & 68.63 & 11.72 & 15.96 & 9.73 & Sandy loam \\
\hline $20-40$ & 1.48 & \multicolumn{2}{|c|}{5.02} & & 67.91 & 12.03 & 15.04 & 11.22 & Sandy loam \\
\hline \multicolumn{10}{|c|}{ b) Chemical properties: } \\
\hline \multirow{2}{*}{\multicolumn{2}{|c|}{ Soil depth (cm) }} & \multirow[b]{2}{*}{ O.M (\%) } & \multirow{2}{*}{\multicolumn{2}{|c|}{$\begin{array}{c}E C \\
\left(d S \cdot m^{-1}\right)\end{array}$}} & \multirow[b]{2}{*}{ pH } & \multicolumn{4}{|c|}{ Nutrient content } \\
\hline & & & & & & \multicolumn{2}{|c|}{ T.N (\%) } & $\begin{array}{l}\text { v. P } \\
\text { pm }\end{array}$ & $\begin{array}{c}\text { Av. K } \\
\text { meq } / 100 \mathrm{~g} .\end{array}$ \\
\hline \multicolumn{2}{|l|}{$0-20$} & 0.32 & \multicolumn{2}{|c|}{1.15} & 7.66 & \multicolumn{2}{|c|}{0.07} & .88 & 0.55 \\
\hline \multicolumn{2}{|c|}{$20-40$} & 0.48 & \multicolumn{2}{|c|}{0.83} & 7.58 & \multicolumn{2}{|c|}{0.04} & .97 & 0.47 \\
\hline
\end{tabular}

\section{Tillage speed and tillage depth}

Tillage speed and tillage depth varied between and within the different treatments. Mean tillage speed during the experiment was $5.72 \mathrm{~km} \cdot \mathrm{h}^{-1}$ for first pass up-downslope tillage treatment, 7.11 $\mathrm{km} . \mathrm{h}^{-1}$ for the second pass up-downslope tillage treatment, $6.20 \mathrm{~km} \cdot \mathrm{h}^{-1}$ for first pass contour tillage treatment and $6.73 \mathrm{~km} . \mathrm{h}^{-1}$ for second pass contour tillage. Tillage depth varied between 7 and $20 \mathrm{~cm}$ for first pass up and downslope tillage treatment, between 14 and $24 \mathrm{~cm}$ for second pass up and downslope tillage treatment, between 12 and 17 $\mathrm{cm}$ for first pass contour tillage treatment and between 18 and $23 \mathrm{~cm}$ for second pass contour tillage, (Table 2). Generally, tillage depths were lowest near the upper slope where the soil is very shallow. The observed variations in tillage depth and speed may be due to differences in the required draught between the treatments as well as 
to the manipulation of the operator in response to changing topography and soil conditions (Lobb et al 1999). There are systematic variations in tillage depth and speed with slope gradients for up and downslope tillage treatments (Fig. 5) (Awady and Salem, 2017). Tillage depth and speed showed no relationship with slope gradients for contour tillage.

\section{Relationship between slope gradient, soil con- dition and soil translocation}

The relationship between the mean displacement distances and the slope gradient for two soil conditions is shown in (Fig. 6). The slope is taken negatively when tracers moved downslope (Poesen et al 1997). The obtained results (show that for the consolidated and loosened treatments, the mean displacement distance of soil after one tillage pass is related to slope gradient. These relationships can be described by linear regression equations as follows:

For the consolidated treatment (up and downslope tillage)

$\Delta x=0.26-1.07 S\left(r^{2}=0.56 ; n=60\right)$

For the consolidated treatment (contour tillage)

$\Delta x=-0.45 S \quad\left(r^{2}=0.88 ; n=10\right)$,

For the Loosened treatment (up and downslope tillage)

$\Delta x=0.37-1.69 S \quad\left(r^{2}=0.70 ; n=20\right)$

And for the loosened treatment (contour tillage)

$\Delta x=-0.68 S \quad\left(r^{2}=0.93 ; n=10\right)$

Where:

$\Delta \mathrm{x}=$ the mean displacement distance of soil after one tillage pass $(\mathrm{m})$

$\mathrm{S}=$ slope gradient $\left(\mathrm{m} . \mathrm{m}^{-1}\right)$

Values for the tillage transport coefficient "K" can then be calculated from equation (1) by using equations 5, 6, 7 and 8 in combination with the data for the bulk density and average tillage depth (Table 1). Resulting "K" values are $256 \mathrm{~kg} \mathrm{~m}^{-1}$ per tillage operation for consolidated soil up and downslope tillage treatment, $454 \mathrm{~kg} \mathrm{~m}^{-1}$ for loosened soil up and downslope tillage treatment, 105 $\mathrm{kg} \mathrm{m}^{-1}$ for consolidated soil contour tillage treatment and $179 \mathrm{~kg} \mathrm{~m}^{-1}$ for loosened soil contour till- age treatment, this implies that tillage erosion rates are much greater for a loosened soil than for a consolidated soil. At the same time, tillage erosion rates are much greater for up and downslope tillage than for contour tillage. These values are in the same order of magnitude as those reported in (Poesen et al 1997).

\section{Effect of chisel tillage and soil condition on soil losses by water erosion}

The most important hazard resulting from water erosion is the removal of the soil from surface. It is known that detachment of soil particles occurs due to rainfall drops and transport process of water erosion occur by runoff. The influence of the applied tillage treatments on the amount of soil loss under natural rainfall intensities is given in (Fig. 7). The highest rate of water erosion resulted from bare soil, at 5.016 ton / ha/year. This rate lies within the permissible limit of soil loss by water erosion, which ranges from 1 to 5 tons / acre/year (Flanagan et al 2007).

With respect to planting consolidated soil with chisel tillage up and downslope, such method reduced the amount of water erosion by $45.6 \%$ relative to bare soil. This behavior could be attributed to the fact that plants protect the soil surface from the energy of rainfall impact. Thereby soil detachment decreased.

Using contour tillage (Fig. 7), for consolidated soil reduced water erosions by $73.7 \%, 51.7 \%$ and $47.6 \%$ as compared with the bare soil. The tillage for consolidated soil in up and downslopes and the tillage for loosened soil in contour tillage, respectively, (Fig. 7), also revealed that tillage for loosened soil in contour tillage reduced water erosions by $76.3 \%, 56.3 \%$ and $52.6 \%$ as compared with bare soil, the tillage for consolidated soil in up and downslopes and the tillage for loosened soil in up and downslopes, respectively. Contour tillage also creates obstruction to water flow over the land, slowing down the runoff velocity, and consequently its carrying capacity thus reducing water erosion.

The data presented in (Fig. 7). reveal that the relative effectiveness of tillage treatments on reducing the rate of soil erosion by water under the conditions of Wadi El-Ramla soils could be arranged in the following descending order: up and downslope tillage for consolidated soil $<$ up and downslope tillage for loosened soil < contour tillage for consolidated soil < contour tillage for loosened soil. 

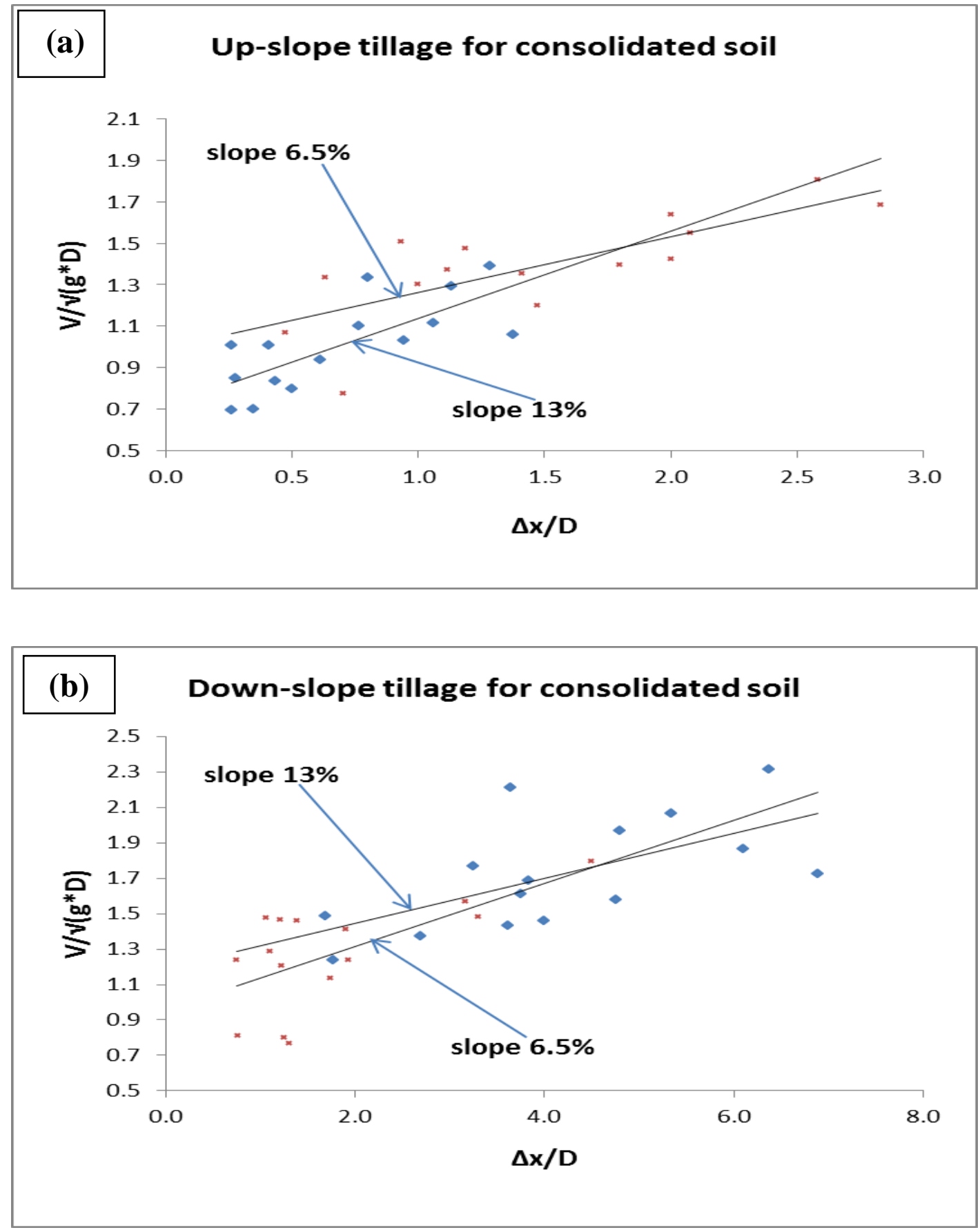

Fig. 5. ( $a$ and b) The relationship between tillage speed "V", tillage depth "D", and average tracer displacement " $\Delta \mathrm{x}$ " for the consolidated treatments 

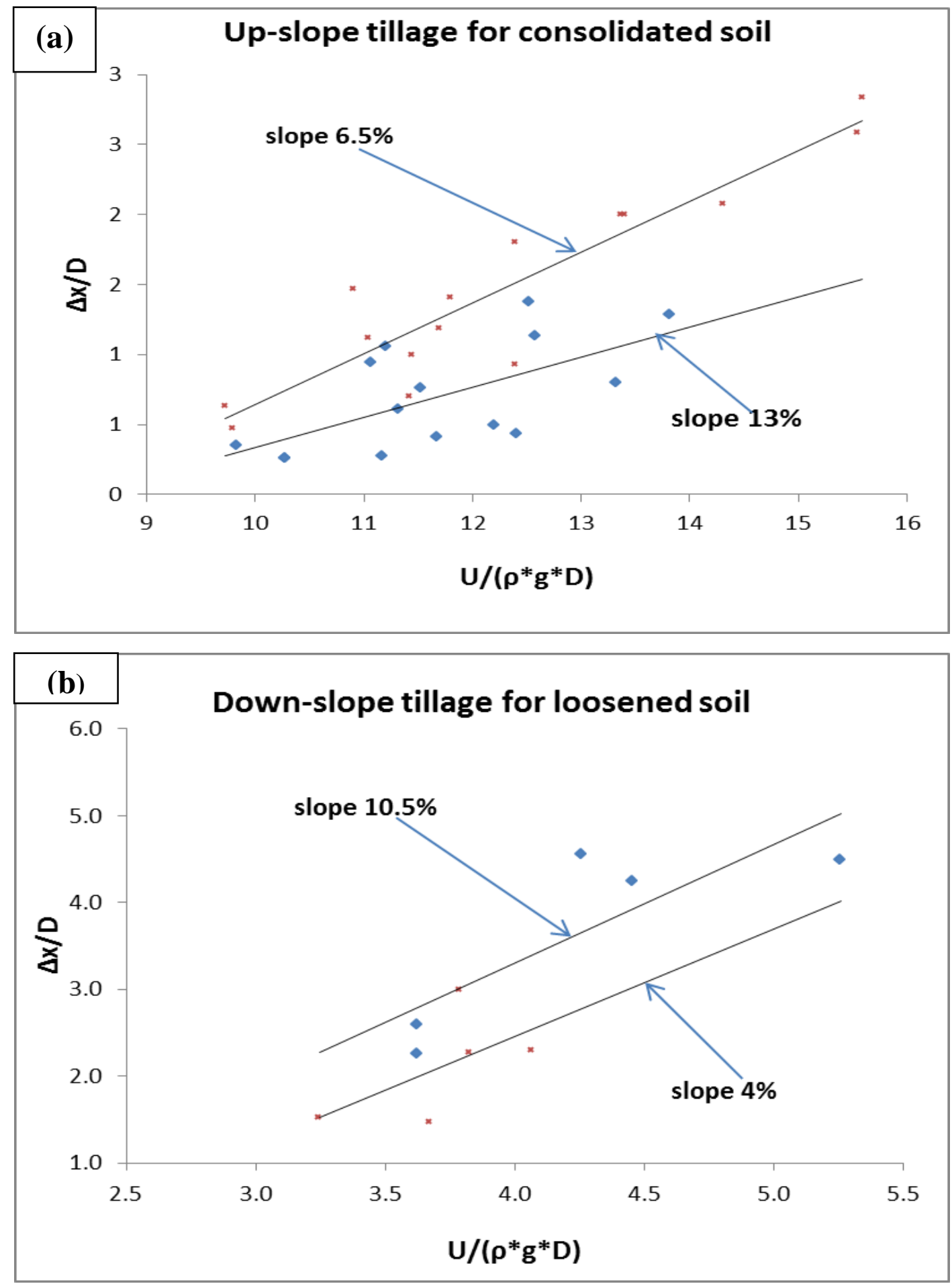

Fig. 6. ( $a$ and b) The relationship between unit draft "U", tillage depth " $D$ ", bulk density " $\rho$ ", slopes "S", and average tracer displacement " $\Delta \mathrm{x}$ " for the consolidated and loosened treatments 


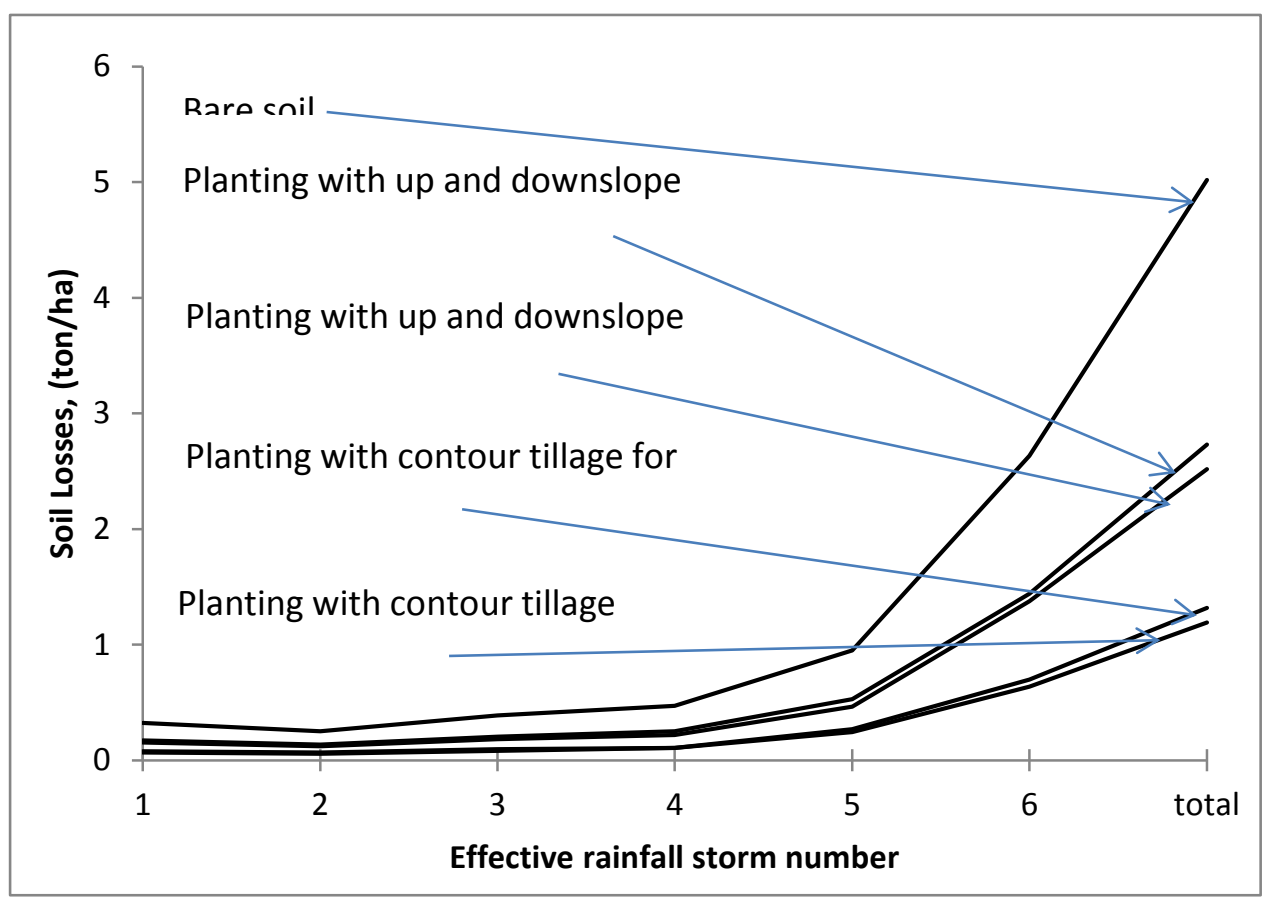

Fig. 7. Effect of chisel tillage systems on soil losses by water erosion

\section{Tillage erosion rates}

Based on equation (3), tillage erosion rates of both soil conditions have been calculated for the hill slope profile at the experimental site as given in Fig. (8). Fig. 8 shows the estimated soil losses as affected by tillage along the studied profiles for a single up- and downslope tillage operations. In case of consolidated soil, maximum local erosion

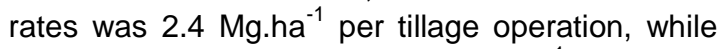
deposition rates amount to $2.7 \mathrm{Mg} \cdot \mathrm{ha}^{-1}$ per tillage operation for specific positions in the field. However, in case of loosened soil, local tillage erosion and deposition rates are two times higher, with soil losses up to $4.3 \mathrm{Mg}$ ha $^{-1}$ per tillage operation and deposition rates up to $4.8 \mathrm{Mg}$.ha-1 per tillage operation. Average erosion values for the convex slope sections are $2 \mathrm{Mg}^{-h^{-1}}$ per tillage operation for the consolidated soil and $4 \mathrm{Mg} \mathrm{ha}^{-1}$ per tillage operation for the loosened soil. These values show clearly that, when preparing consolidated soil for crop production, the second tillage operation is the most erosive, as this tillage operation is responsible for tillage erosion rates which are two times greater than the first tillage operation of the consolidated soil.
Under conventional agricultural practice in the Wadi El Ramla, 2 chisel operations are carried out per year. If tillage always carried out in the up and downslope direction results in tillage erosion rates

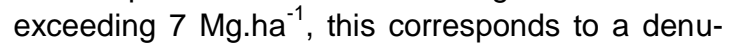
dation rate of approximately $0.5 \mathrm{~mm}$ assuming a soil bulk density of $1500 \mathrm{~kg} \cdot \mathrm{m}^{-3}$. It is clear that soil translocation by tillage will result in soil loss on convex slope positions such as crests and shoulder slopes, because there is an increase in slope gradient. Thus increases soil translocation rate. Conversely, soil deposition will take place in concave slope positions.

\section{Mean displacement distance of the tracers in the direction of tillage prediction}

Van Muysen et al (2000) model used tillage depth, tillage speed, soil conditions and slope gradient in this study as it provided detailed data for individual points. Fig. (8) shows the relationship between the predicted displacement distances ( $d$ pred) calculated using equation (6) and the measured displacement distances (d) in this experiment. Validation indicated that variations in the displacement distance can be successfully predicted. A simple correlation analysis reveals that there is a significant relationship between (d) measured and ( $d_{\text {pred }}$ ). 


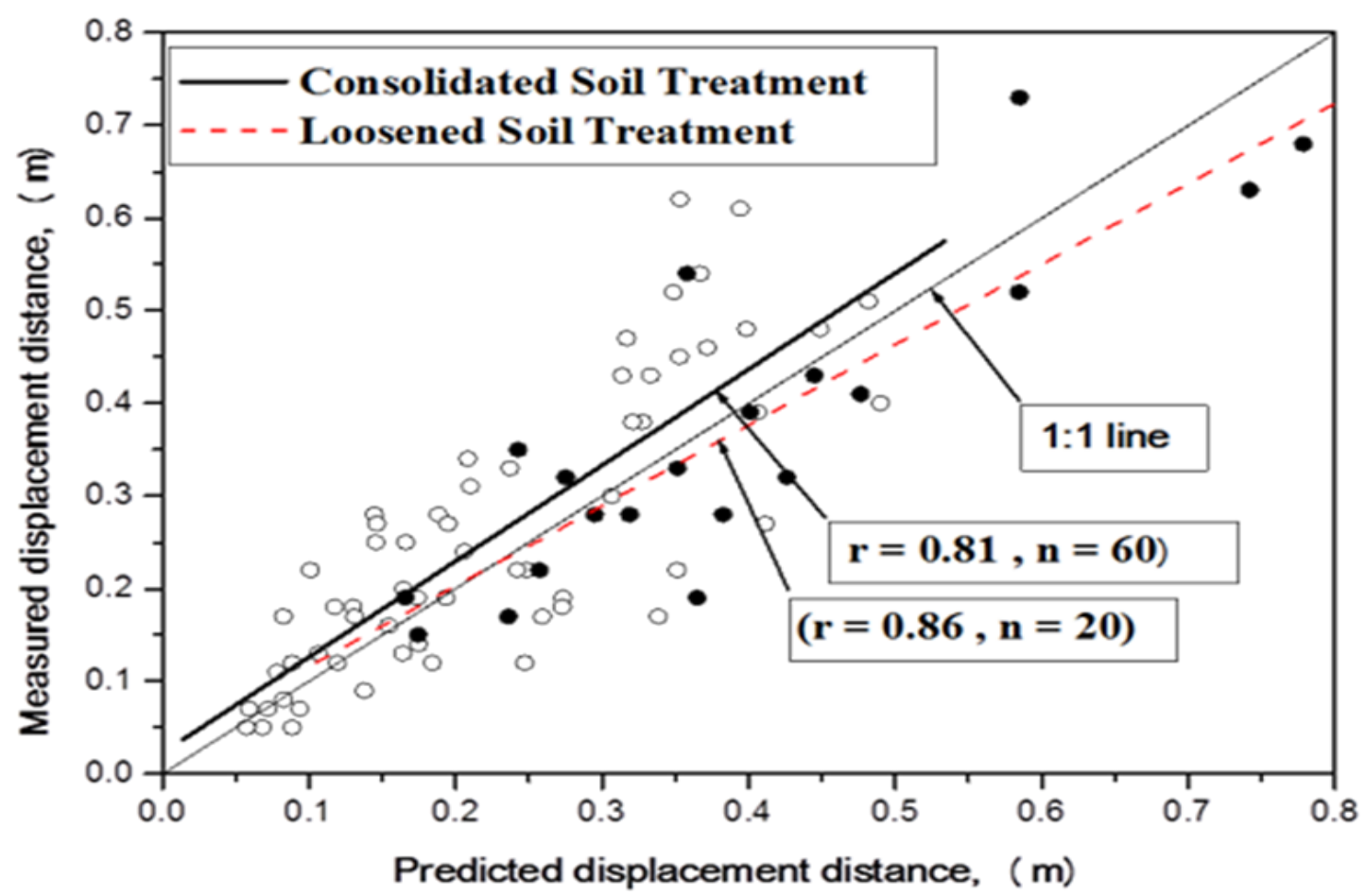

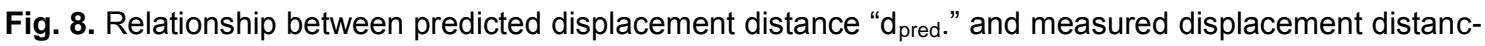
es " $d$ " for the data of this experiment

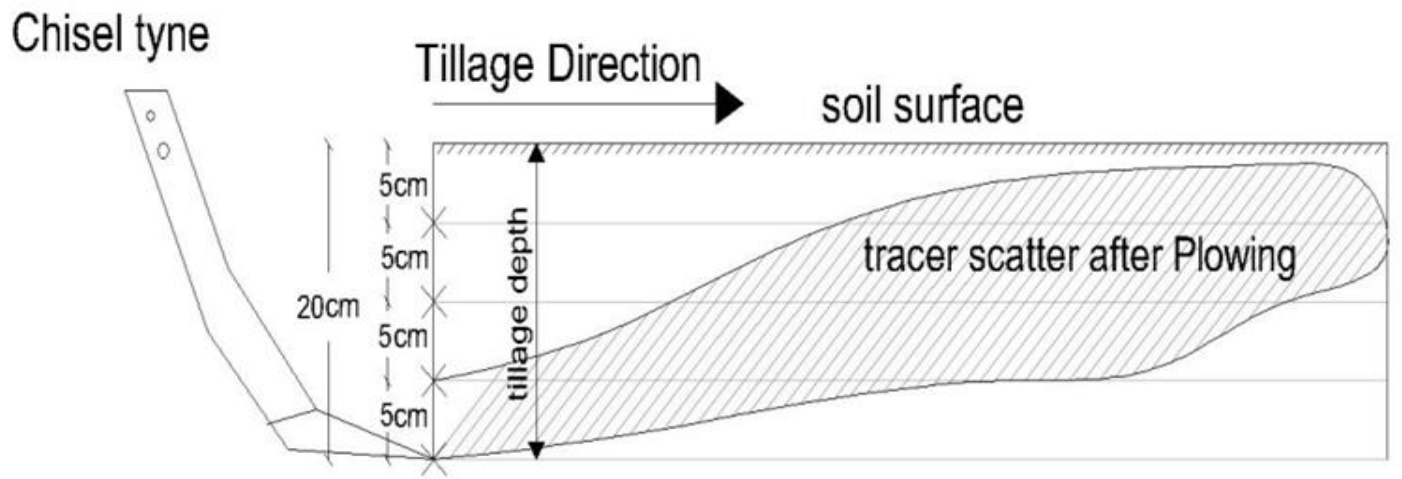

$80 \mathrm{~cm}$

$X$ Location of 10 tracers (every $10 \mathrm{~cm}$ width) at the specified depth

Fig. 9. Relationship between initial tracer depth and tracer displacement distances 
Relationship between initial tracer depth and tracer displacement distances

Fig. (9) clearly shows that a negative relationship exists between soil displacement distances and tillage depth. As increasing tillage depths result in lower mean soil displacement distances. This can be explained as follows: the tracers (and soil) at or near the surface move over relatively large distances, no matter what the tillage depth. This is because their movement is not hampered by the normal stresses exerted by the overlaying soil mass. At greater depth, the displacement distances are relatively smaller, as the soil movement is limited by more important normal stresses. The results indicated that there is a negative relationship between displacement distance and initial tracer depth.

\section{CONCLUSIONS}

From the above mentioned discussion, it is clear that tillage erosion under NW Coast is affected by tillage system, soil condition, slope gradient, tillage depth and tillage speed. The values for tillage transport coefficient "K" was $105 \mathrm{~kg} \mathrm{~m}^{-1}$ per tillage operation for consolidated soil and $179 \mathrm{~kg}$ $\mathrm{m}^{-1}$ per tillage operation for loosened soil under contour tillage treatment, however, $256 \mathrm{~kg} \mathrm{~m}^{-1}$ per tillage operation for consolidated soil and $454 \mathrm{~kg}$ $\mathrm{m}^{-1}$ per tillage operation for loosened soil under up and downslope tillage treatment.

The values for tillage transport coefficient " $k$ " reveal that the relative effectiveness of tillage treatments on reducing the rate of tillage erosion under the conditions of Wadi El-Ramla soils could be arranged in the following descending order: up and downslope tillage for loosened soil < up and downslope tillage for consolidated soil < contour tillage for loosened soil < contour tillage for consolidated soil. At the same time, soil erosion rates due to tillage are much greater for up and downslope tillage than for contour tillage, Where up and downslope chisel tillage is erosive, leading to annual tillage erosion rates exceeding $7 \mathrm{Mg} \mathrm{ha}^{-1}$ locally.

Considering the widespread use of tillage practices in the steep agriculture, the high redistribution rates associated with the process and its direct effect on soil properties is vital and necessary to mitigate land degradation studies.

\section{REFERENCES}

Awady, M.N. and Salem, A.M. 2017. Unpublished analysis and results.

Awady, M.N. 2006. First chapter on machinery and Agricultural Mechanization Introduction to Agricultural Engineering Facul. Ag., Ain Shams Univ. 33 p. Arabic (text)

Dercon, G., Deckers, J., Govers, G., Poesen, J., Sanchez, H., Vanegas, R., Ramirez, M. and Loaiza, G. 2003. Spatial variability in soil properties on slow-forming terraces in the Andes region of Ecuacbr. Soil and Tillage Research, 72, 31-41.

Flanagan, D.C., Gilley, J.E. and Franti, T.G. 2007. Water erosion prediction project (WEPP): development history, model capabilities, and future enhancements. Transactions of the ASABE, 50, 1603-1612.

Govers, G., Lobb, D.A. and Quine, T.A. 1999. Tillage erosion and translocation emergence of a new paradigm in soil erosion research. Soil Till. Res., 51, 167-174.

Govers, G., Vandaele, K., Desmet, P., Poesen, J. and Bunte, K. 1994. The role of tillage in soil redistribution on hillslopes. Eur. J. Soil Sci., 45 (4), 469-478.

Khalifa, M.E. and Beshay, N.F. 2015. Soil classification and potentiality assessment for some rainfed areas at West of Matrouh, Northwestern Coast of Egypt. Soil Tillage Res. 94(2), 425440.

Kimaro, D.N., Deckers, J.A., Poesen, J., Kilasara, M. and Msanya, B.M. 2005. Short and medium term assessment of tillage erosion in the Uluguru Mountains, Tanzania. Soil Tillage Res., 81, 97-108.

Lindstrom, M.J., Nelson, W.W., Schumacher, T.E. and Lemme, G.D. 1990. Soil movement by tillage as affected by the slope. Soil Till. Res., 17, 255-264.

Lindstrom, M.J., Lobb, D.A. and Schumacher, T.E. 2001. Tillage erosion: an overview. Annals of Arid Zone, 40, 337-49.

Lobb, D.A., Kachanoski, R.G. and Miller, M.H. 1995. Tillage translocation and tillage erosion on shoulder slope landscape positions measured using Cs-137 as a tracer. Can. J. Soil Sci., 75, 211-218.

Lobb, D., Kachanoski, R. and Miller, M. 1999. Tillage translocation and tillage erosion in the complex upland landscapes of southwestern Ontario, Canada. Soil Till.Res., 51, 189-209. 
Lobb, D.A., Quine, T.A., Govers, G. and Hekrath, G.J. 2001. Comparison of methods used to calculate tillage translocation using plottracers. J. Soil Water Conserv. 56, 321-328.

Marques da Silva, J.R., Soares, J.M.C.N. and Karlen, D.L. 2004. Implement and soil condition effects on tillage-induced erosion. Soil Till. Res., 78, 207-216.

Poesen, J., Van Wesemael, B., Govers, G., Martinez-Fernandez, J., Desmet, P., Vandaele, K., Quine, T. and Degraer, G. 1997. Patterns of rock fragment cover generated by tillage erosion. Geomorph., 18, 183-197.

Sharifat, K. and Kushwaha, R.L. 1997. Soil translocation by two tillage tools. Canadian Agri. Eng., 39, 77-84.

Sharifat, K., Kushwaha, R.L. and Reed, W.B. 1994. Soil translocation by tillage tools.
Presented at the 1994 International Summer Mtg. of ASAE, Paper no. 941047. ASAE, 2950 Niles Rd., St. Joseph, MI 49085-9659, USA. pp. 977-988.

Turkelboom, F., Poesen, J., Ohler, I., Van Keer, K., Ongprasert, S. and Vlassak, K. 1997. Assessment of tillage erosion rates on steep slopes in northern Thailand. Catena, 29, 2944.

Van Muysen, W., Govers, G., Van Oost, K. and Van Rompaey, A. 2000. The effect of tillage depth, tillage speed, and soil condition on chisel tillage erosivity. J. Soil Water Conserv., 55, 355-364.

Van Muysen, W., Van Oost K. and Govers G. 2006. Soil translocation resulting from multiple passes of tillage under normal field operating conditions. Soil Tillage Res., 87, 218-230. 